\title{
Editor's Note: A New Institutional Home for ILWCH and Other Good News
}

This has been a year of new initiatives at the journal. We are pleased to announce that as of July 2008, ILWCH will have a new institutional home at Rutgers University where the journal will be jointly sponsored by the School of Arts and Sciences and the School of Management and Labor Relations. As part of our new partnership with Rutgers, the journal will mount a biannual international conference on a global labor theme of contemporary and historical interest. The first such conference is scheduled for the spring of 2010.

Other changes are afoot in journal personnel and format. We welcome Kate Brown as our new Book Review Editor, Marcel van der Linden as an Associate Editor, and Mae Ngai, Prasannan Parthasarathi, Don Quataert, and Jean Quataert as new members of our Editorial Board. We have reached out to scholars whose expertise will help us extend the intellectual and global reach of the journal, and we are excited to have them as part of the editorial team.

$I L W C H$ will now be more widely available electronically. The journal is already part of the Cambridge University Press electronic package of journals which has a substantial and growing base of institutional subscribers worldwide. In addition, ILWCH will soon be available electronically through JSTOR, PROQUEST, and EBSCO. Cambridge University Press is also busy digitizing the early volumes of the journal as well as the "European Labor and Working-Class History Newsletter," self-published from May 1972 to November 1975, which was the forerunner to $I L W C H$. These too will be accessible online in the near future.

These changes go hand in hand with the Board's continued commitment to offering readers the best scholarship available on global labor in a variety of formats. We will continue to feature groups of original research articles on a particular theme: Labor and public history, global commodities, and women and working-class politics in India are among those planned for the future. Yet each issue will contain regular ongoing features such as book and film review essays, conference reports, scholarly controversies, interviews with prominent labor activists and scholars as well as essays for the "classics revisited" section. We also plan to publish more contemporary analysis of labor affairs and essays on the "state of labor and labor scholarship" in regions and countries around the world.

This issue is an example of the high standards we aim to maintain. In it, readers will find a scholarly controversy organized by Senior Editor Dorothy Sue Cobble centering on Jefferson Cowie and Nick Salvatore's sweeping reinterpretation of twentieth-century US political history, "The Long Exception: Rethinking the Place of the New Deal in American History." Kevin Boyle, Michael Kazin, Jennifer Klein, Nancy MacLean, and David Montgomery 
offer a refreshingly varied set of pointed commentaries on the article, to which Cowie and Salvatore respond. The issue also includes two reports on important international conferences by Magaly Rodríguez García (Vrije Universiteit Brussel) and Gisela Mettele (University of Leicester); a fascinating essay by William P. Jones for the "Classics Revisited" section in which he reinterprets Eugene Debs's oft-quoted essay, "The Negro in the Class Struggle;" and a stellar group of six research articles introduced by Jefferson Cowie on the theme, "The Conservative Turn in Postwar US Working Class History." Jeff proposed this special issue; he also did the yeoman work of soliciting, reviewing, and editing the six articles which he introduces. $I L W C H$ will miss Jeff's creativity and initiative as a Senior Editor as he moves onto the ILWCH Consulting Board.

Finally, $I L W C H$ would like to welcome our new Managing Editor, Andrea Estepa, and thank Peter Nekola who served as our Managing Editor for eight years with dedication, skill, and patience. We wish him the best with his teaching and writing. We also appreciate the longstanding support given the journal by the New School for Social Research and the intellectual leadership New School faculty member Victoria Hattam provided as Senior Editor.

Dorothy Sue Cobble and Mary Nolan

Senior Editors 